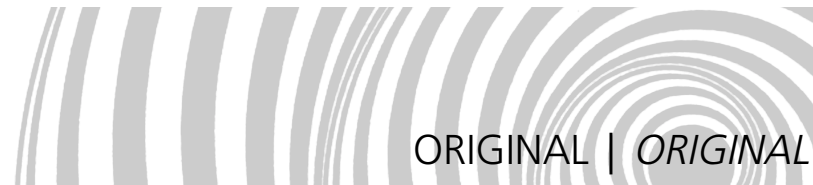

\section{Anemia prevalence in children and adolescents from educational centers in the outskirts of Londrina, PR, Brazil}

\section{Prevalência de anemia em crianças e adolescentes de unidades} educacionais na periferia de Londrina, $P R$

Lúcia Helena da Silva MIGLIORANZA

Tiemi MATSUO ${ }^{2}$

Glenys Mabel CABALLERO-CÓRDOBA ${ }^{3}$

Jane Bandeira DICHI ${ }^{4}$

Edilson Serpeloni CYRINO5

Ivonete Barros Neves de OLIVEIRA ${ }^{6}$

Mary Szantó MARTINS'

Nívea POLEZER ${ }^{7}$

Isaías DICH| ${ }^{4}$

Iron deficiency anemia is the world most prevalent nutritional problem. To investigate anemia prevalence and its relation to nutritional status, 526 children and adolescents, 284 males and 242 females, aged 7 to 14 years old, were evaluated. The studied subjects take part in a program of the Social Action Department of the city of Londrina, state of Paraná, and attend Public Educational Centers which provides them three daily meals and pedagogic assistance. These individuals belong to deprived areas in the city outskirts, where the per capita income is lower than US\$500 a year. The hemoglobin dosage was determined by digital puncture and read by Hemocue portable photometer. Anemia prevalence was verified in $41.3 \%$ of the assessed population, with no significant statistical differences between males and females $(p=0.412)$. No association between anemia and malnutrition was found. In conclusion, high prevalence of anemia was observed in this population.

Index terms: anemia, nutritional status, students.

\footnotetext{
1 Departamento de Tecnologia de Alimentos e Medicamentos, Universidade Estadual de Londrina.

2 Departamento de Matemática Aplicada, Universidade Estadual de Londrina.

3 Departamento de Nutrição, Centro de Estudos Superiores de Londrina.

4 Departamento de Clínica Médica, Centro de Ciências da Saúde, Universidade Estadual de Londrina. Londrina, PR, Brasil. Rua Robert Koch, 60, Bairro Cervejaria, 86038-440. Correspondência para/Correspondence to: I. DICHI. E-mail: dichi@sercomtel.com.br

5 Departamento de Fundamentos da Educação Física, Universidade Estadual de Londrina.

6 Departamento de Ciências Biológicas, Centro de Estudos Superiores de Londrina.

7 Secretaria da Ação Social, Prefeitura Municipal de Londrina.
} 


\section{RESUMO}

A anemia ferropriva é a deficiência nutricional mais encontrada no mundo. Com o objetivo de detectar a prevalência de anemia e sua relação com o estado nutricional, foram avaliadas 526 crianças e adolescentes, na faixa etária de 7 a 14 anos, sendo 284 do sexo masculino e 242 do sexo feminino. A população estudada participou de um programa da Secretaria de Ação Social do Município de Londrina, PR, e freqüenta Unidades Educacionais Públicas que fornecem três refeições diárias e atendimento pedagógico. Estes indivíduos vivem em áreas carentes na periferia da cidade, onde a renda per capita anual é inferior a US\$500. A dosagem de hemoglobina foi realizada mediante punção digital feita por fotômetro portátil. Verificou-se uma prevalência de $41,3 \%$ de anemia, sem diferença significativa entre os sexos $(p=0,412)$. Não houve associação entre anemia e desnutrição. Observou-se, portanto, alta prevalência de anemia nesta população.

Termos de indexação: anemia, estado nutricional, estudantes.

\section{INTRODUCTION}

According to the United Nations Nutrition Committee (Lönnerdal \& Dewey, 1996), anemia caused by iron deficiency is estimated to affect one billion individuals worldwide and is the most predominant form in both developing and developed countries (Yip, 1994). Studies performed in developing countries have demonstrated values around $51 \%$ and $46 \%$ for the anemia prevalence in 0-4 and 5-12 age groups, respectively. Even in regions with higher income in Brazil (Southern and Southeast), the results are of great concern. In São Paulo (the largest city in South America), anemia was detected in $80 \%$ of the children under 5 years of age (Vannucchi et al., 1992). Various nutrient deficiencies are involved in nutritional anemia, but iron is the most important, being responsible for $90 \%$ of the cases (Vannucchi et al., 1992).

Iron deficiency results in important physical and mental disorders, such as: increase of cardiac output, decrease in aerobic metabolism, decrease in mental concentration, increase in infection susceptibility, and cognitive functions damage in young children (Walter, 1996). Its relation to children mental retardation has also been discussed (Hurtado et al., 1999).

Thus, the aim of this study was to describe the prevalence of anemia related to nutritional status in a low income population, aged $7-14$ years old, attending Public Educational Centers in Londrina, PR.

\section{SUBJECTS AND METHODS}

This study, approved by the University of Londrina Ethical Committee, is part of a major nutritional intervention project using iron fortification, developed from August, 1998 to August, 1999. The assessed population belongs to Public Educational Centers in Londrina, PR, and comes from families living in extreme poverty. The annual income is lower than US\$500 per capita, and most of the children's parents (68.7\%) had no more than one year of schooling (data from the local Government Social Department, 1990). The evaluation involved nine Centers, seven in the outskirts of the town (União da Vitória, Vila Ricardo, Fraternidade, Mister Thomas, Novo Amparo, José Belinati and Nossa Senhora da $\mathrm{Paz}$ ), and two in the rural area (Guaravera and Paiquerê).

The Centers, sponsored by the local Government, provide recreation, pedagogic assistance, cultural activities and meals for the individuals under 14 years old. In general, the meals provided by these Centers are this population only access to food.

A cross sectional study was conducted with 526 subjects, aged 7 to 14 years old, who had formal consent signed by their parents.

To evaluate nutritional status, body weight (W) and height $(\mathrm{H})$ values were verified. The weight was obtained from a Urano PS 180 
anthropometric scale with accuracy of $0.1 \mathrm{~kg}$. Height was assessed by a steel anthropometer, attached to the scale, with accuracy of $0.5 \mathrm{~cm}$. All individuals were barefoot and wore only T-shirts and shorts during the measurements.

A Hemocue portable photometer (Angholm, Sweden) was used for hemoglobin dosages (Von Schenck et al., 1986). Samples were collected by digital puncture after a 4-hours fasting period. Anemia was defined at $\mathrm{Hb}$ $<120 \mathrm{~g} / \mathrm{L}$, according to the World Health Organization criteria (DeMaeyer et al., 1989).

Weight and height data were categorized in percentiles according to National Center for Health Statistics (NCHS), considering the sex and age of the individuals (National..., 1981). To evaluate the homogeneity of the distribution of the anemic children and adolescents regarding sex, weight and height ranges, a Chi-square or
Exact Fisher test were used, at a significance level of $5 \%$.

\section{RESULTS}

Of the 526 school aged (7 to 14) studied individuals $54.0 \%(n=284)$ were male and $46.0 \%(n=242)$ were female. In the surveyed population, 217 were anemic $(41.3 \%)$, being $44.4 \%$ males and $37.6 \%$ females, indicating a homogeneous distribution regarding sex $(p=0.138)$. In order to evaluate the anemic children and adolescents, the National Center for Health Statistics percentile intervals for weight and height were chosen considering the amplitude in the age range according to sex. The results of this analysis (Tables 1 and 2) indicate that the distribution of the anemic children and adolescents regarding weight and height percentiles is homogeneous ( $p=0.894$ and $p=0.573$, respectively).

Table 1. Anemia frequency of children and adolescents according to NCHS weight percentile intervals.

\begin{tabular}{|c|c|c|c|c|c|}
\hline \multirow{3}{*}{ Weight } & \multicolumn{5}{|c|}{ Anemia } \\
\hline & \multicolumn{2}{|c|}{ Yes } & \multicolumn{2}{|c|}{ No } & \multirow{2}{*}{ Total } \\
\hline & $\mathrm{n}$ & $\%$ & $n$ & $\%$ & \\
\hline Below $3^{\circ} \mathrm{P}$ & 16 & 7.4 & 16 & 5.2 & 32 \\
\hline $3^{\circ} \mathrm{P} \longmapsto 10^{\circ} \mathrm{P}$ & 19 & 8.8 & 33 & 10.7 & 52 \\
\hline $10^{\circ} \mathrm{P} \longmapsto 50^{\circ} \mathrm{P}$ & 111 & 51.1 & 159 & 51.5 & 270 \\
\hline $50^{\circ} \mathrm{P} \longmapsto 90^{\circ} \mathrm{P}$ & 64 & 29.5 & 91 & 29.4 & 155 \\
\hline $90^{\circ} \mathrm{P} \longmapsto 97^{\circ} \mathrm{P}$ & 5 & 2.3 & 8 & 2.6 & 13 \\
\hline Above $97^{\circ} \mathrm{P}$ & 2 & 0.9 & 2 & 0.6 & 4 \\
\hline Total & 217 & 100.0 & 309 & 100.0 & 526 \\
\hline
\end{tabular}

$\chi^{2}=1.658$ with d.f. $=5 ;$ p-value $=0.894$.

Table 2. Anemia frequency of children and adolescents according to NCHS height percentile intervals.

\begin{tabular}{|c|c|c|c|c|c|}
\hline \multirow{3}{*}{ Height } & \multicolumn{5}{|c|}{ Anemia } \\
\hline & \multicolumn{2}{|c|}{ Yes } & \multicolumn{2}{|c|}{ No } & \multirow{2}{*}{ Tota } \\
\hline & $\mathrm{n}$ & $\%$ & $n$ & $\%$ & \\
\hline Below $3^{\circ} \mathrm{P}$ & 21 & 9.7 & 30 & 9.7 & 51 \\
\hline $3^{\circ} \mathrm{P} \longmapsto 10^{\circ} \mathrm{P}$ & 27 & 12.4 & 40 & 12.9 & 67 \\
\hline $10^{\circ} \mathrm{P} \longmapsto 50^{\circ} \mathrm{P}$ & 110 & 50.7 & 156 & 50.5 & 266 \\
\hline $50^{\circ} \mathrm{P} \longmapsto 90^{\circ} \mathrm{P}$ & 53 & 24.4 & 76 & 24.6 & 129 \\
\hline $90^{\circ} \mathrm{P} \longmapsto 97^{\circ} \mathrm{P}$ & 5 & 2.3 & 2 & 0.7 & 7 \\
\hline Above $97^{\circ} \mathrm{P}$ & 1 & 0.5 & 5 & 1.6 & 6 \\
\hline Total & 217 & 100.0 & 309 & 100.0 & 526 \\
\hline
\end{tabular}

Exact Fisher test $p$-value $=0.573$ 


\section{DISCUSSION}

In the 1980 s, studies showed $26 \%$ of anemia prevalence among Latin American children between 5 and 12 years old (DeMaeyer \& Adiels-Tegman, 1985).

Most of the anemia epidemiological researches in Brazil were specifically related to pregnant women and children under 6 years of age, both groups considered of high vulnerability (Stefanini et al., 1995).

Therefore, studies about anemia prevalence using school age populations are relatively rare in Brazilian community. In the present survey, $41.3 \%$ of the evaluated children and adolescents had anemia. This rate is inferior to the one found by a research conducted in São Paulo (Cesar, 1990), but it is similar to the numbers showed found by a study carried out in the Metropolitan area of the same city, around $41.7 \%$ (Stefanini et al., 1995). The anemia prevalence found in the present study was distinctly superior to that verified in the Northeastern region of Brazil, but it was similar to the prevalence observed in the Northern (Pará), Middle Western (Mato Grosso) and Southern (Rio Grande do Sul) regions (Vannucchi et al., 1992). These data comparison was limited by the definition of anemia used, $110 \mathrm{~g} / \mathrm{L}$ or $120 \mathrm{~g} / \mathrm{L}$. However, it is important to emphasize that, by and large, the high anemia rate verified by this study was due to extremely precarious socioeconomic patterns, added to the low educational levels of the studied families.

As for the nutritional status, $6.1 \%$ of the surveyed population was underweight, below the $3^{\text {rd }}$ percentile for acute malnutrition, and $9.7 \%$ was short, below the $3^{\text {rd }}$ percentile for chronic malnutrition. Both indexes were superior to the index found in the Osasco (SP) public schools, where $3.97 \%$ had chronic malnutrition and no children had acute malnutrition (Stefanini et al., 1995).

As in previous researches (Cesar, 1990; Stefanini et al., 1995), this survey did not find any association between anemia and malnutrition, since the distribution of weight and height was homogeneous among the anemic and non-anemic individuals. This association, however, was observed in studies carried out in Africa (Tatala et al., 1998).

In conclusion, there is a high prevalence of anemia among the school age population in the Public Educational Centers in Londrina, Paraná. Special attention should be given to this particular population in terms of developing and supplying iron fortified foods, increasing the bioavailability and evaluating food intervention efficacy.

\section{ACKNOWLEDGEMENTS}

To Nelson Heitor Fuzinato and the Physical Education, Nursing, Nutritional Sciences and Medical School undergraduate students, for their invaluable technical support.

\section{REFERENCES}

CESAR, A.T. O uso de ácido ascórbico no controle da deficiência de ferro utilizando a estrutura do Programa de Merenda Escolar. São Paulo, 1990. Dissertação (Mestrado) - Faculdade de Saúde Pública, Universidade de São Paulo, 1990.

DEMAEYER, E., ADIELS-TEGMAN, M. The prevalence of anaemia in the world. World Health Statistics Quarterly, Geneve, v.38, n.3, p.302-316, 1985.

DEMAEYER, E., DALLMAN, P.R., GURNEY, J.M., HALLBERG, L., SOOD, S.K., SRIKANTIA, S.G. Preventing and controlling iron deficiency anemia through primary health care. Geneve: World Health Organization, 1989. 58p.

HURTADO, E.K., CLAUSSEN, A.H., SCOTT, K.G. Early childhood anemia and mild or moderate mental retardation. American Journal of Clinical Nutrition, Bethesda, v.69, n.1, p.115-119, 1999.

LÖNNERDAL, B., DEWEY, K.G. Epidemiologia da deficiência de ferro no lactente e na criança. Anais Nestlé, São Paulo, v.52, p.11-17, 1996. 
NATIONAL CENTER FOR HEALTH STATISTICS. Plan and Operation of the Second National Health and Nutrition Examination Survey 1976-1980. Hyattsville MD, 1981. (Vital and Health Statistics Series 1: Program and Collection Procedures, n.19, DHHS Publication, n.(PHS) 85.1321).

STEFANINI, M.L.R., COLLI, C., LERNER, B.R., LEI, D.L.M., CHAVES, S.P., DIPIETRO, M.S., OLIVEIRA, A.A.M., SZARFARC, S.C. Anemia e desnutrição em escolares da Rede Pública do Município de Osasco, São Paulo, Brasil. Cadernos de Saúde Pública, Rio de Janeiro, v.11, n.3, p.439-447, 1995.

TATALA, S., SVANBERG, U., MDUMA, B. Low dietary iron availability is a major cause of anemia: a nutrition survey in the Lindi District of Tanzania. American Journal of Clinical Nutrition, Bethesda, v.68, n.1, p.171-178, 1998.
VANNUCCHI, H., FREITAS, M.L.S., SZARFARC, S.C. Prevalência de anemias nutricionais no Brasil. Cadernos de Nutrição. São Paulo, v.4, p.7-26, 1992.

VON SCHENCK, H., FALKENSSON, M., LUNDBERG, B. Evaluation of "HemoCue", a new device for determining hemoglobin. Clinical Chemistry, Winston-Salem, v.32, n.3, p.526-529, 1986.

WALTER T. Conseqüências não hematológicas da deficiência de ferro. Anais Nestlé, São Paulo, v.52, p.25-35, 1996.

YIP, R. Iron deficiency: contemporary scientific issues and international programmatic approaches. Journal of Nutrition, Bethesda, v.124, n.85, p.1479-1490, 1994.

Recebido para publicação em 4 de setembro de 2000 e aceito em 6 de julho de 2001 . 